CONTRIBUICGAO ȦS MEMORIAS ACADÊMICAS

\title{
Ministro Costa Manso doutor honoris causa
}

Rememorando a solenidade em que o saudoso jurista brasileiro, Manuel da Costa Manso, antigo ministro do Supremo Tribunal Federal, foi homenageado pela nossa Universidade em 1955, que lhe conferiu as honras de doutor, publicamos a seguir os discursos proferidos pelo ilustre e extinto magistrado e pelo professor Ataliba Nogueira, em nome da Universidade de S. Paulo.

Presidiu ao ato o Magnífico Reitor, professor Ernesto Leme.

\section{Discurso do professor Ataliba Nogueira}

Senhor ministro Costa Manso, viestes a esta assembleia universitária a tomar o capêlo, honraria com que vos distinguíu a Universidade de $\mathrm{S}$. Paulo. Por quase meio século usastes as vestes talares. Já agora, sôbre elas, ireis ostentar o capêlo encarnado a cobrir o pescoço, jogado para trás o capús, afim de que pompeie sôbre vossa cabeça a borla doutoral, ornada de franjas e requifes e de outros lavores de sirgueiro.

Repete-se, hoje, aquí, a solenidade que há mais de oitocentos anos as universidades realizam com suntuosidade e ritual medievais. De Bolonha, Paris, Lisboa e Coimbra chegou o ceremonial, em parte, à nossa universidade. Revivamos, pois, o conjunto de atos que constituem a festividade coimbrã do doutoramento, a investidura no mais alto gráu acadêmico, cujas insígnias, não faz muito, para honra da nossa universidade, foram alí impostas com todo fausto ao magnífico reitor Ernesto Leme.

Forma-se o cortêjo aparatoso, destinado a conduzir o doutorando, revestido de béca, à sala dos capêlos. Para- 
ninfa-o um dos professores ou qualquer outro padrinho, previamente convidado. Ao som do hino acadêmico dá entrada no recinto a luzida procissão. Dirige-se o reitor da universidade, acompanhado dos diretores das diversas faculdades para a mesa central, buscando cada um dos catedráticos as respectivas doutorais. Padrinho e apadrinhado têm assento distinto, voltados de frente para a assembleia acadêmica. Vigia, para que se não quebre o protocolo, o mestre de ceremonias, que é o secretário da universidade. Ao padrinho incumbe proferir o discurso laudatório do doutorando. Como, porem, somente algum professor pode então usar da palavra, se o paraninfo não tiver tal qualidade, para tanto é previamente designado um catedrático.

Findo o elogio, procede-se à colação do gráu, em meio ao maior silêncio, quebrado apenas pela leitura pausada e em alta vóz das palavras rituais, procedida pelo reitor, diante da assistência que o ouve de pé. A seguir, coloca à cabeça do doutorando a borla e faz-lhe a entrega do livro e anel doutoral.

Eis já o novo doutor que, em atenção e delicadeza, seguido do secretário, se dirige aos doutorais afim de abraçar um por um os mestres universitários.

\section{Doutores em leis}

Não se trata, entretanto, tão somente de dignidade universitária, pois o gráu acadêmico apenas veio, sob nova forma, continuar a tradição imemorial dos doutores. Nas sagradas escrituras, assinala-se posição de relêvo aos doutores da lei e por tôda a parte, nos mais vetustos monumentos, se nota a alto respeito pelos doutores das leis divinas ou humanas. Se bem que o título, desde o comêco, fosse corrente nos vários ramos das artes e das ciências, foi no campo do direito que tomou maior altura e, juntamente com os mestres teólogos e filósofos, pontificaram 
nas universidades os doutores em cânones ou em leis civis ou mesmo, como até hoje, em várias delas, os doutores in utroque iure.

Naquele repertório de profundo saber jurídico, que são "Las siete partidas del sabio rey don Alfonso el nono", sôbre o qual a poeira do esquecimento não consegue poisar, não obstante os séculos decorridos desde o seu aparecimento, encontramos notas curiosas àcêrca dos doutores em leis. Diz assim: "A ciência das leis é como a fonte da justiça e dela se aproveita o mundo mais do que de outra ciência. Por isto, os imperadores, que fizeram as leis, outorgaram privilegio aos mestrés das escolas, de quatro maneiras. A primeira, que logo tenham o nome de mestres e de cavaleiros e sejam chamados senhores de leis. A segunda é que cada vez que o mestre de direito surja diante de algum juíz, que esteja julgando, deve o juíz levantar-se e saudá-lo e recebê-lo e trazê-lo para junto de sí. Se de outro modo agir, o magistrado está sujeito à pena do pagamento de três libras de ouro. A terceira, que os porteiros dos imperadores e dos reis e dos príncipes lhes não conservem fechadas as portas, nem lhes embarguem os passos para entrar perante eles quando lhes aprouver. E se aqueles estiverem em grande puridade, devem comunicar-lhes sem detença que à porta estão tais mestres e perguntar-lhes se os mandam entrar ou não. A quarta é que sejam subtís e entendidos e que saibam mostrar este saber e sejam bem ponderados e de boas maneiras. Ao cabo de vinte anos que tenham escola de leis, devem ter a honra de condes e, porquanto as leis e os imperadores tanto os quiseram honrar, importa que os reis os mantenham naquela mesma honra. Por isto havemos por bem que os mencionados mestres, em todo o nosso senhorio, tenham as honras que já dissémos, assim como manda a lei antiga".

De quem houvesse de gosar tantos privilégios exigia a segunda Partida que fosse homem de boa fama e de boas maneiras e tivesse desembargada a lingua para 
mostrar o seu bom entendimento do texto e da glosa daquela ciência diante dos maiorais dos estudos. Como nota pitorêsca, acrescenta o dispositivo legal que o candidato há de jurar não ter dado nem prometido qualquer coisa àqueles que lhes outorgaram a licença de ser mestre, nem a outrem por eles.

\section{“Doctor honoris causa"}

Outrora nunca deixaram de estar associadas as posições de doutor e de professor. Doctor etimologicamente indica qui docet, o que ensina ou o que sabe e, por isto, é capaz de ensinar. Se as instituições escolares e mais tarde as universidades reconheceram ao doutor o ius ubique docendi, também já de há muito estas últimas passaram a conceder as mesmas honras que outorgam aos seus doutores àqueles que pelo seu grande saber e pelos seus trabalhos, mesmo sem o título acadêmico respectivo, exerceram o ius ubique docendi. Diriamos que tais laureas acadêmicas outra coisa não são que o reconhecimento pela corporação de que tais expoentes, por sí mesmos, pelo seu valor intelectual, pela sua capacidade, pela sua cultura, muita vez até pelo seu gểnio, se constituiram mestres em determinada arte ou ciência. Mesmo sem a licentia legendi, disputandi, docendi.: hic et ubique terrarum, já leram e explicaram os livros de outros doutores, já disputaram e ensinaram em seus próprios livros os assuntos transcendentes da ciência.

Tal é a vossa altíssima situação, senhor doutor Costa Manso. Se doctor é o que ensina, já tendes ensinado de sobêjo, por bem mais de um quartel de século, sem que esta missão expressamente vos fosse conferida em gráu acadêmico ou, por outras palavras, sem a licença das autoridades universitárias. Sendo assim, reconhece-vos hoje o conselho universitário como digno de ostentar as insignias da láurea conquistada alhures, fóra do recinto acadêmico. 


\section{Os méritos do novo doutor}

Por ocasião do vosso septuagésimo quinto aniversário, nas várias homenagens que vos foram prestadas, notáveis oradores salientaram as principais passagens da vossa biografia, desde a obtenção, em 1895, nesta mesma casa, de dois bacharelados, o de ciências jurídicas e o de ciências sociais, quando a barba ainda vos não pungia no rosto. Tal circunstância, unida à estatura pequena e ao todo franzino, esbatia a prematuridade de inteligência de escol, à qual a pouco e pouco se foi acrescendo cultura geral e cultura jurídica. A advocacia incipiente e a passagem rápida pelo ministério público, sob a orientação moral e intelectual das figuras austeras, embora jovens, de Firmino Whitaker, José Maria Whitaker e Francisco de Barros Penteado, serviram de prelúdio à atuação do magistrado e vincaram profundamente na alma do juíz de Casa Branca os conceitos de honradês e de virtude, hauridos de início na lição e no exemplo paterno. Barros Penteado e José Maria Whitaker foram paradigmas de virtudes profissionais ao jovem advogado e promotor público; Firmino Whitaker, espelho das qualidades do juiz digno deste nome.

Despertaram-lhe os três o gôsto pela ciência jurídica, que lhe consumiu a maioria dos horas, em comarca de movimento relativamente pequeno. Sobejava-lhe tempo para estudo sistemático. Lia de tento e vagar os nossos mestres. Se o aféto entranhado a alguns lhe era deleite das horas feriadas do dia, outros, sem-saborões, nem por isto eram postos de lado. Discorreram anos e se tornou ele homem de claro juizo e ciência bastante, de acume de vista, vingando fama de prudente e de douto.

Em várias outras circunstâncias, tais como em 1929 e mais tarde, ao deixar a presidência do tribunal de justiça, por haver sido eleito ministro do supremo tribunal federal; e mais tarde ainda, ao aposentar-se neste cargo, como por 
ocasião dos já invocados festêjos dos seus setenta e cinco anos de idade, foram salientados os seus dotes de advogado, de membro do ministério público e, sobretudo, de juíz. Não foi por nenhum destes títulos, nem pelos florões que engalanaram a sua atividade nesses vários sectores, que o sr. Costa Manso grangeou a láurea de doutor honorário da nossa universidade. Deve-a aos seus trabalhos jurídicos, embora vários deles constem de pareceres, votos ou acórdãos.

\section{O estudo do direito}

De Casa Branca, em 1915, envia a sua colaboração à comissão incumbida de organizar o projeto de reforma judiciária do estado. Foi "o mais assíduo dos bons auxiliares que o projeto alcançou. Do primeiro ao último dos esboços publicados, a todos dedicou estudo minucioso, remetendo observações e emendas criteriosas, que foram aproveitadas para o acabamento do projeto", tais são as textualíssimas palavras da comissão, composta, para honra desta universidade, pelos ilustres professores Azevedo Marques, Reinaldo Porchat e Gama Cerqueira.

Como a regra geral de todo progresso é o sacrifício, consagrou-se o juíz ao desempenho de suas funções e ao desinteressado estudo do direito, sem preocupação pelo futuro, sem o desassossêgo e a mutabilidade geradas pela correria de comarca a comarca até lograr uma vara nesta capital. Ainda não havia de direito, mas já existia de fato a carreira de juíz. Por paradoxo, tal juíz foi até o inspirador da legislação que diferençou as comarcas segundo várias entrâncias. Fê-lo, porém, segundo pensamos, para corrigir os males da correria que de fato já existia, através do sistema de permutas e transferências. Ele, que passou dezesseis anos como juíz daquela comarca, déz dos quais sem dalí se afastar, sequer para vir a S. Paulo; ele, que conhecia o exemplo de magistrados como Whitaker, Soriano de Souza, Júlio de Faria e outros, que 
por tempo ainda maior permaneceram na mesma comarca, onde não só distribuiram bem a justiça como espalharam a fama dos seus feitos, sabia sem dúvida da conveniência daquela estabilidade que, longe de impedir, foi até propiciadora de tais méritos. Vieram diretamente de comarcas pequenas para o tribunal de justiça do estado quase todos aqueles brilhantes magistrados.

\section{A obra do jurista}

Tomou assento em fulgurante constelação de juízes. Já era julgador e jurista de renome. E pôs-se a trabalhar. Salientou, desde logo, a necessidade de novo regimento interno, cujo anteprojeto lhe saíu da pena, o qual, com as modificações e acréscimos necessários é o mesmo ainda hoje em vigor. $E$ que se trata de obra de jurista basta atentarmos aos profundos estudos a que se dedicou para a sua feitura, os quais redundaram na publicação do seu livro "Processo na segunda instância e suas aplicações à primeira", engenhoso trabalho sistemático, revelador de extrema clareza de espírito e penetrante argúcia. Combate a rotina ou preconiza a observância antes do texto da lei que das corruptelas e vícios dos estilos illegais. Suas críticas e sugestões encontraram guarida em futuras leis e de modo especial nos códigos de processo que daí por diante surgiram em vários estados da união.

Várias leis de organização judiciária e de processo nasceram de anteprojetos de sua autoria, dentre outras a reforma do juri e a do regimento geral das correições.

Mal chegado ao supremo tribunal federal, acolheramse desde logo as suas propostas de reforma do regimento interno, a de divisão do tribunal em turmas e outras providências tendentes ao aceleramento da justiça. Quanto à divisãc daquela suprema côrte em turmas, combatí-a eu, bem mais tarde e com êxito, na constituinte de 1946. Não obstante a vitoria da minha emenda, excluindo do 
artigo a possibilidade do fraccionamento do supremo tribunal, continúa ele ainda hoje com a divisão em turmas, proposta por Costa Manso e fôrça é reconhecer que para a presteza da justiça assim fica melhor, embora sob certo aspécto e a meu ver se sacrifique a sua majestade.

O labor do jurista encontramo-lo nos seus três livros e em numerosos opúsculos de monografias, cuja lição com frequência é invocada.

\section{O código processual de S. Paulo}

Importa, sobretudo, salientar a sua atuação ao ser elaborado o código de processo civil e comercial do estado de S. Paulo. Com a honrosa exceção de Costa Manso, todos os demais membros da comissão elaboradora do anteprojeto foram professores de direito.

A orientação geral firmada foi a de tomar o direito vigente em sua pureza, sem as deformações e alterações abusivas, dar-lhe melhor sistematização e aperfeiçoá-lo, simplificando, precisando e modernizando institutos ou méros dispositivos. Tal obra, mesmo antes de provar bem, passou a influir na legislação de outros estados e em numerosos passos inspirou o atual código de processo civil, fruto da unificação dêsse ramo do direito pátrio.

A incursão pelo trabalho de Costa Manso e companheiros, se nos situarmos exatamente no momento da promulgação do código paulista, patenteia-se o aperfeiçoamento a que chegou, no Brasil, o direito processual civil. Por exemplo, no tocante à competência, possibilitou que a mulher intentasse a ação de desquite ou de nulidade ou anulação de casamento no fôro da sua residência, quando houvesse sido abandonada pelo marido. Colocou de lado a regra de que o fôro havia de ser o do casal, isto é o do marido. Para as ações reais o princípio do domicílio passou a ser a regra, o que trouxe inovação nas divisões e demarcações de imóveis situados em mais de uma cir- 
cunscrição judiciária. Passaram a correr no lugar do ato ou fato, onde a prova é mais fácil e segura, as ações de reparação de dano e as de gestão de negócios. A competência passou a ser regulada definitivamente pela decisão proterida em conflito de jurisdição, que, devia mandar reunir no juízo competente os diversos processos, unificando-os e aproveitando os atos válidos praticados no juizo incompetente.

No tocante à intervenção de terceiro, ficou bem definida a oposição. Alargou-se a esféra assinada aos embargos de terceiro. Surge renovado o concurso creditório, para atender ao desejo de fazer justiça efetiva.

Quanto aos atos e termos processuais, desponta a novidade do registro geral dos feitos de todo o estado no tribunal de justiça, tendo como fonte o registro de cada comarca. Criou-se a duplicata dos autos para acautelar a retenção, desvio ou pêrda dos originais. Dispensou-se o escrivão da redação de complicados termos de vista, conclusão, juntada, remessa e outros, bastando que, com a sua rubrica, constem simples notas datadas, que provem o movimento dos feitos no pretório. Instituíu-se a precatória telegráfica. Autorizaram-se as partes e testemunhas a ditar os seus depoimentos.

Grande inovação foi a referente aos prazos, quebrando-se assim um dos motivos de absurdo protraimento da justiça. Dispôs o código que os prazos corressem geralmente da intimação ou da vista e terminassem independente de lançamento. Ainda para o aceleramento dos feitos ficou estabelecido que o réu seria absolvido da instância, quando o autor não preparasse os autos para julgamento no prazo de trinta dias. Tôda a disciplina dos embargos de declaração visou à economia processual, desde a sua oposição, no prazo restrito de quarenta e oito horas, até à sua rejeição in limine, quando manifestamente protelatórios. Neste último caso, perdiam até o efeito suspensivo, com prejuízo para a interposição de recursos posteriores. Os litigantes de boa fé lograram o dispositivo 
que estatuíu poderem ser retificados a todo tempo, independentemente de formalidades, os êrros de escrita, de cálculo e outras inexatidões evidentes das sentenças.

Se há um capítulo daquele notável monumento juridico, em que maior influência se nota da ação do ministro Costa Manso, é o relativo às nulidades processuais, exclusivamente da sua lavra, em que aproveitou a sua larga experiência de julgador e o seu profundo saber doutrinário. Contrariamente a tudo que tínhamos como disciplina da matéria, passou a distinguir, em enumeração minuciosa, os atos judiciais nulos e os anuláveis, segundo o critério estabelecido no código civil para os atos jurídicos, adaptando-o de modo conveniente aos atos judiciais. Surge pela primeira vez, quanto aos atos e termos substânciais, a sua discriminação em dois grupos, num deles os que são indispensáveis a todos os processos e noutro, os essenciais a cada processo em particular. Quer a nulidade, quer a anulabilidade ficam sujeitas à prova de prejuizo e hão de ser rejeitadas, quando o ato possa ser repetido ou emendado ou quando lhe haja dado causa o arguidor ou a pessoa em cujo benefício reverteu. Apresenta-se com cautelosa disciplina a ação rescisória de sentença, na qual se permite a cumulação dos judicia rescindendum e rescisorium.

Dando de mão às novidades concernentes aos processos preparatórios, preventivos e incidentes, iremos encontrar no processo tanto de primeira quanto de segunda instância dispositivos originais, cự̂a enumeração alongaria demasiado esta nossa análise. A principal, todavia, foi a de estabelecer como processo comum a ação sumária, se levarmos em conta que foi ela estendida a inúmeras relações de direito e às causas de valor até cinco mil cruzeiros, que era bom limite para aquela época.

Pela primeira vez no Brasil se seguíu, na classificação dos processos especiais, a ordem das matérias do código civil, desde os processos relativos às pessoas fisicas e jurídicas até os concernentes aos testamentos, inventários, arrolamentos, heranças jacentes e todo o direito das sucessões. 
Por sua vez, a execução da sentença e os recursos, no então novél código, são capítulos em que o aperfeiçoamento da técnica, a precisão das regras e a severidade contribuiram, como se viu mais tarde, para tornar expedita a justiça e para a moralização do fôro.

Em estudo divulgado no mesmo dia da publicação do código de processo civil e comercial do estado de S. Paulo, em 1930, o sr. ministro Costa Manso previu muito bem que ele havia de constituir o alicerce de construção definitiva. De fato nele auriu boa parte dos seus preceitos o atual código de processo civil, promulgado para todo o Brasil. Nos dispositivos eliminados do anteprojeto pela comissão elaboradora ou ainda posteriormente pelo poder legislativo paulista, havia excelentes medidas, muitas das quais preferiveis até ao texto aprovado.

Neste sector do direito processual, havemos de recordar, ainda, a sua preocupação de tornar a justiça rápida, sem a deturpação ou o desfiguramento dos institutos jurídicos tradicionais.

Foi o ministro Costa Manso precursor da ação declaratória, cuja disciplina regulou em minucioso projeto, precedido de brilhante justificação.

Com o mesmo intúito assinalado, no Supremo tribunal federal fixou a verdadeira inteligência do direito certo $e$ incontestável, como requisito para a concessão do mandado de segurança. Não se tratava tanto de subtilêsa, embora subtil fosse a questão, mas de clara visão jurídica.

\section{O doutor em leis}

Todo este labor não é bem próprio do juíz, nem do advogado, funções em que pontificou ou ainda pontifica, tendo atingido em cada qual a mais alta situação. $\mathbf{E}$ trabalho do jurista. Se já as outras corporações lhe prestaram as devidas homenagens, manifestando-lhe assim o 
regosijo por tê-lo como expoente da classe, justo era que a universidade de S. Paulo tambem o fizesse ao cientista do direito, conferindo-lhe as honras de doutor.

Percebe-se, em tôda a sua vida, a fé no ideal científico e, como meta de seus estudos e de seus trabalhos, a construção e a sistemática do direito, reconhecendo a existência e a necessidade dos repertórios de jurisprudência, mas compreendendo que para o jurista há de ser a casuística tão só instrumento de investigação, afim de desdobrar-se o instituto em todos os seus aspectos para lhe fixar a visão unitária e a respectiva finalidade. Daí o seu desassossêgo, a sua inquietação ao verificar impraticável certa lei como instrumento de justiça e o divórcio tanto da lei como da doutrina e a realidade, o que sem dúvida lhes acarreta o desprestígio popular. Esta a causa das suas numerosas iniciativas de renovação do direito positivo.

Não consiste o culto da justiça tão só na observância da legalidade, nem com ela pretende confundir-se. Quando descansamos na ordem estabelecida ou inertemente aguardamos que a justiça cáia do alto, não estamos assim verdadeiramente respondendo à vocação da nossa consciencia jurídica. Impõe-nos tal vocação a participação ativa e indefessa no drama eterno, que tem por teatro a historia e por tema o contraste entre o bem e o mal, entre o direito e o torto. Não devemos somente obedecer às leis, mas ainda vivificá-las e cooperar na sua renovação.

E por isto que aos juristas não é permitido afastaremse dos problemas concretos da vida real, pois, se assim o fizerem, estarão contribuindo para a diminuição do senso do direito no povo. Carece que ele veja no direito o meio insubstituível para a atuação da justiça, colocadas de lado as soluções por demais rudimentares da decisão segundo a equidade, do juíz legislador e da decisão caso por caso, inspirando-se em critério de justiça abstrata ou atendendo às diretivas de orientação política. Não é o jurista somente o intérprete da lei, mas é tambem o técnico, o 
cientista, o investigador para a criação das novas leis. Em face da tripartição do poder público, diriamos que ele não pode ter assento no poder judiciário, pois a sua tarefa volve-se para o legislativo e para quanto de discrecionário se reconhece lícito ao chamado poder executivo.

Daí o caminho natural do jurista para a política, o qual só não foi trilhado por Costa Manso, não obstante haver aceito o convite do ilustre sr. dr. Plínio Barreto para secretário da justiça de $\mathrm{S}$. Paulo, porque o rigido paulista não quís assumir o cargo de interventor federal, segundo me consta, para evitar luta fratricida, originada da grande exacerbação de ânimo entre os políticos adversos.

\section{Elogio do direito da monarquia}

Continuemos, porem, as considerações que faziamos a respeito do jurista, para acrescentar que, embora elemento de progresso, ele não há de romper a continuidade histórica. Pelo contrário, há de respeitar os augustos monumentos legislativos. Eis aquí tambem outra legítima feição do espírito científico da obra do novo doutor da universidade de S. Paulo. É o seu profundo saber a respeito de tôda a nossa legislação, conhecimento raro na maioria dos nossos cultores do direito, versados no direito peregrino, profundos na obra de autores estrangeiros, mas votando manifesto desprêso, seja pela nossa antiga legislação, seja pelos nossos venerandos jurisconsultos. Tratando-se de espíritos eminentes e cultos, tal desamor só se explica pela ignorância dos monumentos que nos legaram os nossos antepassados e das lições que mestres insuperáveis escreveram.

Nos domínios do direito processual civil, então, a posição assumida pelos juristas brasileiros em geral e em especial pelos paulistas é de todo em todo injustificável, visto como até o advento do código de processo civil e comercial do estado de S. Paulo, ou seja até 1930, boa parte 
do direito vigente (c.p.c. e comercial, art. 1.160) era do livro terceiro das Ordenações do Reino de Portugal, promulgadas por el rei dom Felipe II, pela carta de lei de 11 de janeiro de 1603, completado por algumas disposições das mesmas Ordenações do livro primeiro e por diversas leis extravagantes, pelos assentos e estilos da Casa da Suplicação de Lisboa e da Relação do Porto.

Costa Manso fez o elogio do código filipino e da construção científica, que qualifica de estupenda, dos jurisconsultos reinícolas, especialmente os praxistas: Silva, Cabedo, Velasco, Pegas, Guerreiro, Morais, Lobão, Menezes, Pereira e Souza e Correia Teles. Não omitiu os seus continuadores, neste lado do Atlântico: Teixeira de Freitas, Ribas, Paula Batista, Morais Carvalho, Ramalho, João Monteiro, João Mendes, Aureliano de Gusmão, nomes quase todos de filhos e mestres desta casa.

Como é interessante o estudo do nosso doutor ao mostrar os vícios e corruptelas que invadiram o direito escrito, deturpando os preceitos das Ordenações do Reino. "As Ordenações, diz ele, reagiram fortemente contra a lentidão da justiça, que irrita as partes e embaraça a prosperidade pública. A praxe, porém, criou formalidades que não constavam da lei, transformando o processo, de simples e ao alcance de todos, que era, em ritual complicado e pesado, somente manejável pelos iniciados."

Adúz alguns exemplos, como o das Ordenações do livro terceiro $\left(20, \S 4^{\circ}\right)$ : Impunha-se ao juíz que ouvisse as partes no comêço da demanda e pelas suas respostas proferisse imediatamente a sentença, se lograsse completo esclarecimento. Se por esta forma desaparecia a questão de fato, restando apenas a aplicação do direito, inútil se tornava o aparato dos articulados, dilações, arrazoados e mais formalidades. O fanatismo da forma havia inutilizado a salutar providência e o interrogatório inicial desapareceu de todo.

Se, ao contestar, mostrasse o réu que o adversário era carecedor de ação, havia o juíz de, desde logo, dar a sua 
sentença (Ordenações cit., $\S 16$ ). A praxe, entretanto, suprimiu mais esta providência e não obstante prescrita a ação, por exemplo, arrastava-se ela até o fim, em longa demanda, para só então ser inutilizado tudo quanto se praticou.

Outro preceito das Ordenaçoes declarava peremptórios os termos e prazos, sendo as partes negligentes havidas por lançadas, muito embora o adversário não acusasse a contumácia ( $\S 44)$. Criou o fôro, porém, os lançamentos formais como condição indispensável ao encerramento dos prazos.

Prescrevía a Ordenação, para se abreviarem as demandas, que se julgasse segundo a verdade sabida, ainda que o processo estivesse mal ordenado, porque, dizia o legislador com imensa sabedoria, o objetivo do processo é a realização da justiça pela apuração da verdade e aplicação do direito (Ordenações, tit. 63). Não obstante tal preceito, a teoria das nulidades acolheu vultoso número de deturpações e abusões para estatuir a anulação de demandas pelo inadimplemento de formalidades que, embora importantes, não mudariam a face das coisas.

\section{Exemplo de vida dignificante}

Em seu labor jurídico, o sr. ministro Costa Manso foi ao mesmo tempo conservador e progressista. De um lado sempre se mostrou partidário da fidelidade às nossas raizes históricas, que geraram a nossa própria individualidade como nação e de outro, sem negar o passado, sôbre ele colaborou na construção da nossa grandeza futura.

Não nos inscrevemos entre os pessimistas, que ante as ingentes dificuldades do momento, ante os grandes desajustamentos sociais, ante os paradoxos que caracterizam a nossa civilização desconhecem ou desprezam a considerá- 
vel obra realizada no Brasil pelo nosso escol social, constituido, em quatro séculos de marcante atuação, pela Igreja, pelas instituições políticas e pelos institutos culturais, primeiros núcleos das nossas universidades. Possuimos escol social, onde encontrar os mentores e guías do povo, exemplares de austeridade, molimes de progresso, munimes das nossas tradições, cadinho dos bons costumes e das virtudes do povo brasileiro. Falta-nos algo? Sim. É que os progressos da técnica desajustaram escol social e povo, de tal maneira que os apêlos do primeiro não encontram éco na alma popular, nem os seus exemplos espelho na massa. Não negamos ser preciso acrisolar a cultura, alargá-la e intensificá-la, estimular o bem e a virtude, recriar o hábito do trabalho e do cumprimento do dever, infundir os sentimentos de generosidade e de grandeza de alma, propiciar os gestos cavalheirescos e inspirar as ações generosas, insuflar o gôsto pelo bem e pelo belo, reintroduzir os hábitos morigerados e o amor à simplicidade. Todo êste apanágio do escol social, vivificado pela doutrina cristã, precisa chegar ao povo, precisa ser conhecido do povo e sobretudo precisa impôr-se à consideração, estima e imitação do povo, como obra da classe social dirigente, que, como dissemos, surgiu no Brasil dêstes três fatores: a Igreja, as instituições políticas e a universidade, pelos institutos que lhe constituiram o germe inicial. Os mesmos três fócos importa continuarem a gerar o escol social brasileiro. A deturpação de qualquer deles, os seus desvios ou êrros, a anulação de sua influência serão de funestas consequências.

Se já não se quer mais a ascendência da Igreja, com o acêrvo da doutrina cristã, com a prática dos mandamentos e sacramentos, com a oração e as honras que cabem a Deus, primeiro dever da criatura para com o Criador; se as instituições políticas têm o deliberado propósito de pôr de lado o escol social, que fez o Brasil tal qual é; se as universidades e demais instituições culturais 
abdicam da sua missão formadora, orientadora, educadora, para se reduzirem a méras escolas técnicas, então já não se pode mais lamentar que o escol social se tornasse inoperante, desfigurado, praticamente inexistente $e$, ao invés de trabalhar pelo Brasil, sirva consciente ou inconscientemente o anti-Brasil.

Suposto, entretanto, que o nosso escol social queira ser fiel ao que é brasileiro, às nossas tradições, às virtudes nacionais de que tanto havemos de nos orgulhar, pois poucos povos as têm tão numerosas; suposto que o escol social deseje eficazmente colaborar na obra da tradição, que não exclúi o progresso, resta o problema a que já aludimos de fazer chegar o éco de sua vóz até o povo e arrastar as massas. São elas conduzidas pelas fôrças incoerciveis do rádio, da televisão, do cinema, da imprensa e dos esportes. Importa que, por meios sugeridos pela inteligência, pela argúcia e pelo tacto e não pela coerção, as instituições políticas coloquem aquelas forças ao serviço da cultura, tarefa do escol social. Nesta tarefa, tambem como primeiros obreiros na reconstrução da grandeza nacional hão de estar os agricultores, comerciantes e industriais. São as chamadas classes conservadoras, que, como tais, e como detentoras de cabedais economicos e financeiros, têm por obrigação cooperar para que aqueles instrumentos de divulgação do pensamento, dos hábitos, da vida e costumes do escol social cheguem até o povo e avassalem as massas. Só assim o escol social não será esmagado pela demagogia nem pela plutocracia. E poderá influir na formação e orientação do povo.

Volvamo-nos de novo a falar diretamente ao ilustre homenageado. Sr. ministro Costa Manso: agradecendo os discursos com que recentemente vos saudaram no Tribunal de justiça, dissestes que o vosso caminho na vida "fôra aplainado pela graça de Deus e pela bondade dos homens." Assinalastes com isto as paralelas em que deve correr a existência humana. 
Os vossos méritos pessoais, porem, traçaram bem alto a vossa posição no escol social brasileiro, a indicar-nos o caminho para a formação de homens doutos, dignos herdeiros das gerações que nos precederam, capazes de contribuir de maneira eficáz para a defêsa do nosso patrimonio de civilização cristã, que só ele pode preservar a recaída da humanidade na barbaria de êrros funestos e costumes corruptos e torná-la apta às mais altas e felizes ascenções nos caminhos da verdade e do bem.

\section{Discurso do ministro Costa Manso}

Esta solenidade adquire, para mim, extraordinário relêvo, por ser celebrada no suntuoso Palácio que hoje ocupa o lugar do velho mas inesquecível edifício, onde iniciei e terminei as minhas provạs escolares, dês dos exames de preparatórios.

Permití que retorne, por um momento, à minha vida escolar.

Quando, em 1888, comecei a estudar, só existia em São Paulo um estabelecimento de ensino superior - a Faculdade de Direito, mais conhecida por Academia de Direito. Só existia, igualmente, um curso oficial de preparatórios - o Curso Anexo à mesma Faculdade, que, por ser o abrigo dos preparatorianos, chamados bichos, era denominado "o Curral" Os dois estabelecimentos, com direção comum, mas com docentes próprios, funcionavam no mesmo prédio - a Faculdade à esquerda e o Curso Anexo à direita.

O preparatoriano podia estudar onde, com e com quem quizessem. Os exames, entretanto, que eram parcelados, abrangendo toda a matéria da respectiva Cadeira, tinham de ser prestados no Curso Anexo.

Passei para a Academia em 1892. A situação moral do estudante não melhorava logo após êsse trânsito. A primeira Cadeira do curso jurídico fôra, antigamente, a de Direito Natural. E como as Institutas do Imperador Jus- 
tiniano definiam - "jus naturale est, quod natura omnia animalia docuit", acrescentando que êle não dominava somente os homens, "sed omnium animalium quae in celo, quae in terra, quae in mari nascuntur", eram os simples bichos, inominados, que para aqui se transportavam, convertidos numa determinada espécie de irracionais chamados calouros. Essa tormentosa fase terminava quando o estudante, passando para o segundo ano, readquiria a sua personalidade humana. .

O estudo do Direito era, no meu tempo, regido por um estatuto de feição positivista, obra do Ministro Benjamim Constant. Imperava a liberdade. Era facultativa a frequência e, por isso, desaparecera o livro de chamada. Não havia sabatinas nem provas parciais. $O$ Lente subia à Cátedra, dissertava sôbre o ponto do dia e se retirava, sem o menor contacto com os alunos. Mas a Cidade ainda era pequena, sem muitas diversões. Os rapazes, não tendo outra cousa que fazer, ou outro lugar mais aprazível aonde ir, reuniam-se na Faculdade. $E$ até havia quem fôsse ouvir os Mestres. Assim, durante aquele máu período escolar e apesar dele, permaneceu vivo o espírito acadêmico.

Havia três Cursos distintos: o de Ciências Jurídicas, que habilitava o bacharel para a Advocacia, o Ministério Público e a Magistratura; o de Ciências Sociais destinado aos que pretendiam fazer carreira na Administração Pública ou na Diplomacia; e o de Notariado, para os candidatos a Ofícios de Justiça. Concluí, em 1894, o primeiro daqueles Cursos e, em 1895, o segundo.

E parti para o trabalho, supondo-me capaz de praticar o Direito: os que menos sabem são os que pensam que tudo sabem... O bacharel recem formado ainda se move na planície, só avistando o acanhado horizonte que as alturas circundantes restringem. À medida que progride, vai-se alongando o diâmetro desse horizonte, e ele percebe que o campo do Direito a vastidão do infinito. $O$ jurista 
envelhece estudando, sem atingir a plenitude da cultura jurídica. E morre delirando, talvez, com os problemas que ainda não pudera resolver. É que o Direito, ciência e arte - ciência e arte de legislar, de ensinar, de postular, de julgar - não se deixa aprisionar em fórmulas invariáveis ou em espaços limitados. Cada caso, cada hipótese - e os casos e as hipóteses variam sempre como as folhas das árvores - reclamam novas investigações. Cada modificação da vida coletiva ocasiona a formação de novas doutrinas, cuja aplicação desde logo se impõe, antes, mesmo, que o legislador as transforme em normas de direito positivo. E nunca se chega ao fim...

\section{Senhores!}

Como a Pátria, que o viajante e o exilado levam no coração e na lembrança, a Faculdade de Direito de São Paulo se conserva no pensamento dos seus filhos. Quem daqui partiu, transpondo as lindes geográficas do "Território Livre", que circunda a Pátria Intelectual dos bachareis; quem daqui partiu, impregnado pelo ideal do Direito e da Justiça, recolhendo, no carisma do gráu, a nobreza da sua missão e o sentido da sua vida, daqui partiu sem se afastar do ponto depar tida. Então, ao rever esta Casa, nas suas modificações arquitetônicas, onde os velhos muros cederam espaço aos novos, que, entretanto, se arqueiam nos antigos moldes; na sucessão do seu corpo docente, em que refulgem os moços, mas sobrepaira, tutelar, o exemplo dos Mestres de outrora; na renovação dos seus discipulos, em que as gerações se vão, mas permanecem os vínculos de poesia e de civismo - então, ao revêr esta Casa, o bacharel de outros tempos como que contempla, nas linhas das arcadas, no símbolo da Congregação, na imagem da juventude, o próprio espírito jurídico, que é tradição e progresso, estabilidade e avanço, conservação e reforma. .

Quanto tempo se passou depois da minha formatura! E que tempos! Neste meio século, os mais surpreendentes acontecimentos precipitaram todas as atividades humanas, 
num rápido, tumultuário $\mathrm{e}$ gigantesco progresso. No transcorrer da minha vida, testemunhei a aparição, ou, pelo menos, o desenvolvimento de quase todas as invenções modernas.

De tais acontecimentos resultaram profundas modificações dos hábitos individuais e coletivos; o advento de diferentes regimes políticos e sociais; a derrocada de doutrinas; o retôrno de filosofias; novas idéias e concepções, convivendo, não raro, em contraste com as fórmulas antigas velhos preceitos renascendo, por sua vez, em antagonismo com outros postulados contemporâneos; expansões comerciais extraordinárias, indústrias gigantescas, grandezas e misérias económicas, tremendas guerras mundiais, com todo o cortejo de imprevisíveis consequências...

O Direito, que é a própria regulamentação do convívio social - ubi societas ibi jus - havia de correr sobressaltos, de entrar em crises de evolução, de adaptar-se, de enriquecer-se, de modificar-se e de resistir muitas vêzes à tirania das inovações precipitadas, tão nefastas quanto o continuismo da rotina.

Um ditador romano, arguido de proceder ilegalmente, respondeu, diz a História, que o barulho das armas o impedia de ouvir a voz das leis. Nos tempos hodiernos, infelizmente, não é só o rugido dos canhões, o espoucar das bombas, as labaredas dos incêndios que têm suficado o império das leis. É também o estrépito das máquinas multifárias, o vozerio das massas populares desnorteadas, as retumbâncias do dirigismo demagógico. Quando não é a mudez sangrenta dos povos oprimidos, ou o silêncio morno das sociedades sem fibra, tapando os ouvidos à palavra do Direito e aos reclamos da Justiça.

A época em que vivemos está, portanto, inçada de glórias e destroços. E não há luta, não há vitória, não há derrota que se não reflitam no ordenamento das normas jurídicas.

Em tais embates, penso haver aprendido que ainda muito ignoro: 
Há mais cousas no céu, há mais na terra, do que sonha a tua vã filosofia.

já nos advertira Shakespeare no Hamlet.

Fiz-me, por isso, um permanente estudante das disciplinas jurídicas, ou, digamos, um estudioso, vocábulo com que o vernáculo, na riqueza dos seus matizes, lisongeia os alunos graduados... Amoldou-se o meu espírito, não à complacência com o êrro, mas à melhor compreensão das atitudes divergentes. Procurei, por igual, não ser dogmático nem cético. Esforcei-me, quanto pude, em acompanhar a evolução natural dos tempos, em abrir o entendimento às legítimas conquistas da inteligência, em aceitar, de bom grado, não só como útil, mas como imprescindivel, a experiência, a colaboração e o ensino dos outros povos, juridicamente mais amadurecidos.

Mas penso que o Direito, assim como a língua e a religião, há de se manter fiel ao gênio do País. Não se enriquece o Direito com simples matéria de importação. Maior fidelidade às fontes nacionais, melhor e mais carinhoso estudo dos nossos grandes mestres, eis, a meu ver, um imperativo à consciência jurídica dos nossos tempos. Um dos lídimos jurisconsultos desta Casa, o saudoso Prof. Francisco Morato, dedicou a êsse tema o notavel discurso que proferiu na sessão inaugural do Instituto dos Advogados de São Paulo:

“patente na expressão diáfana franceza (dizia êle), envolto na forma brumosa do germanismo ou de qualquer modo apadrinhado pelo sainete de fora da terra, o que é peregrino seduz-nos e comove-nos como expressão de verdades porventura flutuantes acima de nossa intelectualidade".

E observava: - "dissertando sobre os traços fundamentais que distinguem os pactos adjectos das condições, escreve um dos nossos mais estimados civilistas que o genial Teixeira de Freitas, sem haver lido os autores 
alemães, conseguira adivinhar qual a verdadeira doutrina na matéria. Merece ser aplaudido o elogio; com maior razão e mais gostosamente, no entanto, houvera de sê-lo (concluia o Prof. Morato) se o douto escritor tivera dito que os autores alemães, sem lerem Teixeira de Freitas, lograram acertar com a verdadeira natureza dos pactos adjectos"...

Recaiu esta sessão solene na data em que se comemora o advento da Constituição de 1891.

É-me grata a circunstância. Êsse Código Político se apresenta em os nossos fastos jurídicos como um alto e nobre momento. Uma obra que, tecnicamente, raia pela perfeição.

Mas tenho para comigo ser mais avisada a filosofia de Solon, que, interpelado sobre se procurava elaborar para a sua Pátria a mais perfeita das constituições, redarguiu:

- não a mais perfeita; sim, a que mais lhe convém...

Sob êste aspecto, penso que a Constituição de 1891 se colocou muito adiante do nosso estado de civilização. E, porisso, jamais foi integralmente cumprida. Todavia, seja qual for o conceito em que a tenhamos, é a expressão fiel de uns tantos ideais extremamente caros às tradições desta Casa e fundamentais à estrutura política do Brasil. Dentre êles, a república, a sujeição das leis e atos administrativos ao controle judiciário e a federação.

Darei, ainda que em poucas palavras, especial relêvo a êste último princípio. Para Rui Barbosa, era o federalismo tão essencial à vida da Nação, que êle, o maior dos paladinos da legalidade, aderiu a um golpe de fôrça, a fim de instaurá-lo.

Com efeito, não se concebe País tão vasto e com tão diferentes aspectos regionais sem uma sólida união largamente descentralizada. Só um bem entendido federalismo pode garantir-nos a coesão da unidade na projeção da variedade. Mas é equívoco supor que, no regime federativo, o problema consista em unificar o politico e 
descentralizar o administrativo. A centralização política acarreta a centralização administrativa, tanto quanto a descentralização administrativa há de repousar na política, pois administração e política são termos de um mesmo binômio. O que importa, assim, é distinguir, com equilibrio e clareza, as respectivas esferas de ação, os limites da competência político-administrativa da União e dos Estados.

$O$ assunto, em face da Constituição de 1891, mereceu lúcido e acurado estudo do eminente Professor Ernesto Leme, hoje Magnífico Reitor da nossa Universidade. Seus trabalhos, depois reunidos num só livro - "A Intervenção Federal nos Estados" e "O Art. 63 das Constituição" - escritos no início de sua vitoriosa carreira, traçaram perfeitamente as lindes da competência federal e da estadual. Infelizmente, porém, a projeção de idéias unitárias, imprescindíveis ao triunfo do chamado Estado Novo, contribuiu para que as Constituições de após 1930 dispusessem muito estritamente sôbre a competência legislativa dos Estados. Federalista tipo 1891, penso que a tendência centralizadora perturbará, ao invés de dilatar, o progresso do Brasil.

Em matéria de Direito Processual, por exemplo, o advento dos Códigos Nacionais extinguiu a possibilidade de regularem os Estados a matéria segundo as suas peculiaridades regionais. Não é possivel submeter ao mesmo regime as Comarcas do Amazonas e de Sergipe, as de Mato Grosso e de São Paulo, as de Goiás e do Rio Grande do Sul.

A multiplicidade dos Códigos Estaduais não levou as vinte e uma unidades da Federação a divergirem no estabelecimento dos princípios fundamentais do processo. Todos êsses Códigos obedeceram ao sistema tradicional, que herdamos dos portugueses, e que viemos modernizando a partir do decr. n. 737, de 1850. Admita-se, entretanto, que tais princípios devam figurar numa lei federal. O restante, porém, deveria caber aos Estados. A Consti- 
tuição vigente nem sequer manteve a competência dos Estados para a legislação subsidiária processual.

Note-se que a própria legislação ordinária tem deformado o que ficou para os Estados. E contra a invasão, principalmente no que concerne à organização judiciária e à competência jurisdicional, a ela inerente, não tem havido a necessária resistência. O Juri, por exemplo, é um Tribunal Estadual, uma vez que não figura entre os que o art. 94 da Lei Fundamental reservou para a União. $O$ mesmo acontece relativamente aos órgãos judiciários incumbidos de julgar, em primeira instância, os delitos de imprensa e os praticados em prejuizo da economia popular. A lei federal, entretanto, foi que creou o denominado Tribunal Popular e regulou a estrutura de todos os três. No processo civil, o Código Nacional dispõe, entre outras cousas, sobre a formação das turmas nos Tribunais de Justiça, sobre a competência para o julgamento de ações rescisórias, convertendo o sábio sistema antigo numa espécie de recurso de que quase todos os litigantes se utilizam, abarrotando inutilmente as pautas dos tribunais.

O tecnicismo conspira, aqui, contra os Estados, porque tende a dilatar o poder de atração e do predomínio do direito material sobre o formal, atravez de deduções doutrinárias inteiramente 'abstratas. Mas o legislador, ao elaborar os preceitos da lei positiva, o jurista e o juiz, ao infundirem inteligência à norma legal, não devem librarse nas asas da teoria pura, a fim de se conservarem fieis à magnitude das suas funções político-sociais e manejar, com espírito realista adequado às circunstâncias do País, a arte e a ciência da legislação e da jurisprudência.

É tempo de se tentar o revigoramento das prerrogativas locais. Ainda agora, São Paulo se vê de novo a braços com o periódico problema do congestionamento de sua Justiça. O nosso Tribunal é um dos maiores do mundo. Já se desdobrou num Tribunal de Alçada, que eu teria denominado Tribunal Estadual de Recursos, ad instar do Federal. Outros já se anunciam. Entretanto, inicia- 
tivas mais fecundas, reformas de base, inteiramente justificadas pelo crescimento ciclópico do nosso Estado, vão sendo tolhidas, seja por disposições processuais inválidas em face da Constituição, seja pela timidez com que são aplicadas as normas federativas por ela reconhecidas.

Penso que a competência do Tribunal de Justiça podeia ficar limitada a certas funções das mais elevadas, constantes do art. 124 da Constituição Federal e 55 e 56 da Estadual, principalmente: a direção, composição, movimentação e disciplina da Magistratura; julgamento, originário ou em gráu de recurso, quando denegados, dos pedidos de habeas-corpus; julgamento originário dos pedidos de mandado de segurança contra atos do próprio Tribunal, do Governador e dos Secretários de Estado; solução de conflitos de jurisdição ou de competência entre quaisquer autoridades estaduais; processo e julgamento das revisões criminais; unificação da jurisprudência dos Tribunais inferiores, no tocante às leis estaduais e municipais (quanto às federais, existe o recurso extraordinário); processo e julgamento das ações rescisórias, se não retornarmos ao antigo sistema. Todos os recursos, civeis e criminais, passariam para os Tribunais Estaduais de Recursos.

A Constituição Federal prevê a existência de um Tribunal de Justiça em cada Estado e no Distrito Federal, mas não enumera todas as suas atribuições. Observado, portanto, o art. 124, podem os Estados regular essas atribuições como for mais conveniente. De outro lado, o inciso II do mesmo artigo permite a creação de Tribunais de menor alçada. "Alçada", no sentido em que foi a palavra empregada, é o mesmo que competência jurisdicional. Ela não se mede, portanto, pelo valor da causa, unicamente, mas também pela qualidade. Pode-se, logo, adotar, sem vício de inconstitucionalidade, a organização que sugiro. Mas se houver receio, que fiquem no Tribunal de Justiça as grandes causas, cujo valor seja superior a alguns milhões de cruzeiros... 
O Tribunal de Justiça ficaria reduzido a quinze ou dezesseis desembargadores. Para isso, e a fim de não serem muito prejudicados os juizes inferiores, em cada duas vagas uma somente seria preenchida. Os Tribunais de Recursos poderiam ser desdobrados em Tribunais Civís e Tribunais Criminais. E. assim, especializados, pequenos, mais rápidos e accessíveis, melhor distribuiriam a Justiça, de modo menos penoso para os julgadores e mais conveniente para os litigantes.

Vejo, senhores, que me alongo demasiadamente. Invoco, para minha escusa, as palavras do insigne Pedro Lessa, no magnífico discurso com que recebeu Alfredo Pujol na Academia Brasileira de Letras: "quem, no Brasil, falando ou escrevendo, não é, pelo menos, um pouco derramado?"

Magnífico Reitor e egrégios Professores!

Durante uma vida inteira, jamais exerci oficio estranho às atividades jurídicas: fui apenas soldado da lei e do Direito. Mas, soldado raso, não esperava merecer o generalato a que, com o título de doutor honoris causa, vós, doutores de fato e de direito, generosamente me promoveis. É um galardão excelso, que recebo comovidíssimo. Agradeço profundamente o laurel que me liberaliza a Universidade de São Paulo, nova, ainda, mas já de decisiva influência no aprimoramento do ensino científico brasileiro.

Quando o notavel estadista Armando de Sales Oliveira lançou os fundamentos desta grandiosa instituição, abriuse uma fase de indisfarçavel importância para a história do pensamento nacional. Só a creação de um verdadeiro espírito universitário, com o imprescindivel concurso de mestres estrangeiros e a arregimentação dos legítimos valôres da nossa própria cultura, tornará extinguir ou atenuar eficazmente os males advindos do auto-didatismo e da improvisação científica.

Na pessoa do seu Magnífico Reitor, o eminente professor Ernesto de Morais Leme, apresento ao egrégio Conselho Universitário as minhas homenagens. 
É o Magnífico Reitor uma de nossas mais formosas expressões de carater e de inteligência. Paulista ilustre, descendente de ilustres paulistas, jurista renomado, parlamentar completo, homem público de escól, cidadão emérito, é êle um dos mais altos valores da cociedade brasileira. Enche-se de justificado orgulho a honra, que S. Excia. me concedeu, promovendo, com tanta simpatia e estima, a presente solenidade.

Agradeço ao sr. Professor José Carlos de Ataliba Nogueira as generosíssimas palavras com que me saudou, emprestando o brilho de sua oratória ao empenho amigo de realçar a minha pessoa. Nas suas preciosas - "Memórias para a História da Academia de São Paulo" - já não escapara ao espírito arguto do Prof. Spencer Vampré as qualidades intelectuais do estudante Ataliba Nogueira. Os fatos confirmaram plenamente os vaticínios que se esboçavam. No trato pessoal e profissional, que mantive com S. Excia., quando desempenhei as funções de Procurador Geral do Estado, pude bem aquilatar dos merecimentos do então representante do Ministério Público paulista. Acompanhei depois a sua trajetória, continuamente ascendente. Orador, jornalista, advogado, parlamentar, polemista, professor que versa com maestria diferentes e árduas disciplinas, lider católico dos mais conceituados, vernaculista e autor de numerosas obras de Direito e de literatura, S. Excia. tem sabido impor-se à justa admiração dos seus contemporâneos.

Na pessoa de seu dinâmico Diretor, o ilustre prof. Braz de Souza Arruda, viva e generosa inteligência, sempre voltada ao estudo dos fenómenos jurídicos e sociais, estendo à egrégia Congregação da Faculdade de Direito os meus agradecimentos $\mathrm{e}$ as minhas homenagens.

Os Antigos Alunos vieram trazer-me a manifestação da sua preciosa solidariedade, pela vibrante palavra do Sr. Desembargador Pedro Chaves, astro de primeira grandeza da nossa Magistratura e amigo dos mais queridos. Abraçando-o, abraço aos velhos e novos amigos, que por aqui passaram. 
Minha terra, a Princesa do Norte, a formosa namorada do magestoso Paraíba, que, deixando o seu curso, vai beijar-lhe os pés; a mãe fecunda de inúmeros brasileiros, que tanto se têm distinguido nas ciências, nas artes, nas belas letras, na política, na imprensa e em todas as manifestações da inteligência; minha terra aqui está presente, dignamente representada por delegação de escol. Quis ela projetar um raio de luz sôbre o coração do velho filho, que sempre a amou, e que, até hoje, tem na memória o traçado das suas ruas, a estrutura dos seus palácios, a lindeza das montanhas que lhe alteiam o horizonte e, sobretudo, a bondade da sua gente.

A S. Eminência o Sr. Cardeal Arcebispo Metropolitano, a S. Excia. o Sr. Representante do Governador do Estado, ao Exmo. Sr. Desembargador Presidente do Tribunal de Justiça, às altas autoridades civís e militares, aos meus amigos, aos meus companheiros de jornadas forenses, à juventude acadêmica, à imprensa - a todos, enfim, que aqui compareceram ou de outro modo prestigiaram esta festa universitária, confesso a minha profunda gratidão.

Por certo, todos vós, na pessoa de um velho servidor da Justiça, quisestes externar o vosso apreço à própria Justiça - à Justiça, que no dizer enérgico de Santo Agostinho, é o que permite distinguir um reino de um covil de salteadores, um príncipe de um capitão de piratas. E quisestes expressar a vossa fé na perenidade, na grandeza, na vitória do Direito.

É comovido que repito a velha fórmula romana, estudada nos bancos acadêmicos: Juris praecepta sunt haec: honeste vivere. alterum non laedere, suum cuique tribuere.

Viver honestamente, não prejudicar o próximo, dar a cada um o que é seu - que é isto senão uma definição jurídica e, ao mesmo tempo, uma prédica do Evangelho?

Assim, no mesmo vértice da moral cristã, se encontram as leis humanas e as divinas...

- Meus senhores! Eu vos agradeço. 